\title{
Letter
}

Int Neurourol J 2013;17:41

http://dx.doi.org/10.5213/inj.2013.17.1.41

pISSN 2093-4777 · eISSN 2093-6931

\section{Bladder Failure: Still a Frontier; Commentary on "Bladder Failure?" (Int Neurourol J 2012;16:209-10)}

Jang Hwan Kim

Department of Urology, Yonsei University College of Medicine, Seoul, Korea

To the editor:

The main function of the bladder is to store and excrete urine in a personally and socially acceptable manner while not harming the upper urinary tract. Although bladder failure can suggest compromise of one or both bladder functions, it generally implies failure in excretion via decreased bladder contraction. Research on nerve stimulation and stem cell transplantation has generated excitement in the past but has yet to produce any clinically significant therapy. This is probably a consequence of the complex nature of the voiding process, which goes further than our current understanding. What is urgent is that the population is aging rapidly and the incidence of bladder failure will inevitably rise rapidly with the aging of the population. Therefore, we need to refocus or share the attention paid to the bladder that is "overactive" with its "underactive" sibling. Perhaps we can borrow ideas from research on heart failure. However we do it, we need to recognize that bladder failure is still a frontier that deserves our attention more than ever.
Corresponding author: Jang Hwan Kim

Department of Urology, Yonsei University College of Medicine,

50 Yonsei-ro, Seodaemun-gu, Seoul 120-749, Korea

Tel: +89-2-2228-2319 / Fax: +82-2-312-2538 / E-mail: jkim@yuhs.ac

Submitted: March 27, 2013 / Accepted after revision: March 30, 2013
This is an Open Access article distributed under the terms of the Creative Commons Attribution Non-Commercial License (http://creativecommons.org/licenses/by-nc/3.0/) which permits unrestricted non-commercial use, distribution, and reproduction in any medium, provided the original work is properly cited. 